\title{
Evaluation of antidiabetic activity of aqueous extract of Origanum floribundum Munby leaves in alloxan induced diabetic rats wistar
}

\author{
M'hamed Nasri, ${ }^{1}$ Mohamed Zaouani, ${ }^{2}$ Noura Mimoune, ${ }^{3}$ Fatma Amira Hani, ${ }^{2}$ Mohamed Mahdid, ${ }^{1}$ \\ Mohamed Toumi ${ }^{4}$ \\ ${ }^{1}$ Laboratory of Ethnobotany and Naturel Substances, Department of Natural Science, École Normale Supérieure (ENS), \\ Algiers; ${ }^{2}$ Laboratory of Food Hygiene and Quality Insurance System, Higher National Veterinary School, Algiers; \\ ${ }^{3}$ Laboratory of biotechnology related to animal breeding, Institute of Veterinary Sciences, University Saad Dahleb, Blida; \\ ${ }^{4}$ Department of Nature and Life Sciences, Faculty of Sciences, University Benyoucef Benkhedda, Algiers, Algeria
}

\begin{abstract}
The present study aimed to evaluate the phytochemicals and the antidiabetic properties of Origanum floribundum aqueous extract. Phytochemical screening was conducted by using various standard procedures. Acute toxicity of the extract was determined by OECD guidelines 423 . The antidiabetic activity of the plant was determined by alloxan-induced diabetes in Wistar albino rats. Data obtained showed the detection of various secondary metabolites such as alkaloids, flavonoids, saponins, terpenoids in the extract. No mortality was observed during acute toxicity studies up to the dose of $2000 \mathrm{mg} / \mathrm{kg}$. The aqueous extract presented the ability of reducing blood glucose levels. These findings indicated that Origanum floribundum aqueous extract had various phytopharmacological activities and thus it would be useful to isolate
\end{abstract}

\footnotetext{
Correspondence: M'hamed Nasri, Laboratory of Ethnobotany and Naturel Substances, Department of Natural Science, École normale supérieure (ENS), Vieux Kouba, 16308, Algiers, Algeria.

Tel.: +213661708571.

E-mail: mhamed.nasri@g.ens-kouba.dz
}

Key words: Aqueous extract; diabetes, rats; Origanum floribundum; acute toxicity.

Conflict of interest: The authors declare no conflict of interest.

Ethics approval: All the experiments were carried out according to the guidelines of the Institutional Animal Care Committee of the Algerian Higher Education and Scientific Research (Agreement Number 45/DGLPAG/DVA.SDA.14).

Received for publication: 25 May 2020.

Accepted for publication: 8 September 2020.

${ }^{\circ}$ Copyright: the Author(s), 2020

Licensee PAGEPress, Italy

Journal of Biological Research 2020; 93:9141

doi:10.4081/jbr.2020.9141

This article is distributed under the terms of the Creative Commons Attribution Noncommercial License (by-nc 4.0) which permits any noncommercial use, distribution, and reproduction in any medium, provided the original author(s) and source are credited. and characterize the compounds responsible for these bioactivities in the future.

\section{Introduction}

Diabetes mellitus is a metabolic disorder characterized by a chronic elevation of blood glucose levels due to disturbances of carbohydrate, fat and protein metabolism. This may result from defects in production, secretion and action of insulin. ${ }^{1}$ In longterm, it can cause serious diseases, such as retinopathy, nephropathy neuropathy, and/or cardio-vascular illnesses. These complications can lead to death. ${ }^{2}$ An average of 425 million adults had diabetes worldwide in 2017, and this number is predicted to rise to 629 million by $2045 .^{3}$ Interestingly, the WHO also reported that diabetes will be the seventh cause of death in $2030 .{ }^{4}$ The incidence and prevalence of diabetes have continued to increase globally, despite a great deal of research with the resulting burden resting more heavily on tropical developing countries. Type 2 diabetes, once considered a disease of industrialized nations, is now becoming increasingly prevalent in Algeria and other emerging countries, ranking as the fourth most prevalent disease. ${ }^{5}$ Despite the significant progress made in the treatments of diabetes over the years in modern therapeutics, the use of herbal medicines for the treatment of diabetes mellitus has gained importance worldwide. Besides, the demand to use natural products with antidiabetic activity is becoming increasingly important, because of several disadvantages that have been reported related to the use of the oral hypoglycemic agents including reduction of efficiency, side effects, and even toxicity. ${ }^{6}$ This influences researchers to focus towards natural products for less or no side effects and low-cost future drug development strategies. ${ }^{7}$ The majority of traditional antidiabetic plants await proper scientific and medical evaluation for their ability to improve blood glucose control. In Algeria, Origanum genus includes two species: glandulosum Desf, which is common over northern Algeria and endemic to the Algerian and Tunisian areas and floribundum Munby, which is rare, endemic to the north-central part of Algeria. ${ }^{8}$ Traditionally, the whole plant is used in the treatment of bronchial pulmonary, digestive and urinary infections and possesses spasmolytic, antitussive and expectorant properties but to our knowledge, there is no scientific study available that reports the anti-hyperglycemic activity of Origanum floribundum. Therefore, the current study was performed with the objective to evaluate the antidiabetic potential of Origanum floribundum aqueous extract in rats' model. 


\section{Materials and Methods}

\section{Plant collection and identification}

The aerial parts of Origanum floribundum were collected in May 2019 in the El Hamdania locality, Chrea National Park of Blida region (Altitude of $800 \mathrm{~m}$; Latitude of $36^{\circ} 210 \mathrm{~N}$; Longitude of $2^{\circ} 450 \mathrm{E}$ ) at $50 \mathrm{~km}$ south of Algiers, Algeria. Identification of the plant was confirmed by Higher National Agronomic School, Botany Department (Algiers, Algeria). A voucher specimen was deposited at the Giffen Herbarium in the Laboratory of Ethnobotany and Naturel Substances, Department of Natural Science, High Normal School, Vieux Kouba, 16308, Algiers, Algeria for future reference.

\section{Aqueous extract preparation}

In this work, $100 \mathrm{~g}$ of Origanum floribundum powder leaves were macerated for 24 hours in $1 \mathrm{~L}$ of distilled water. The macerate has been filtered twice through cotton wool, then through the Whatman filter paper (Number 1). The filtrate was evaporated to dryness using under vacuum in a rotary evaporator at $40^{\circ} \mathrm{C}$. After that, it was lyophilized using the lyophilizer for 12 hours and the collected product was preserved in a refrigerator at $4^{\circ} \mathrm{C}$ for further use.

\section{Experimental animals}

Healthy young adult male and female with an average weight of $200 \pm 20 \mathrm{~g}$ Wistar albino rats were obtained from the Pasteur Institute of Algiers. Control and treated animals were housed separately in sterile polypropylene cages under standard environmental conditions (temperature of $22 \pm 3{ }^{\circ} \mathrm{C}$, relative humidity: $55-65 \%$ and $12 \mathrm{~h} \mathrm{light/dark} \mathrm{cycle).} \mathrm{They} \mathrm{were} \mathrm{fed} \mathrm{with} \mathrm{basic} \mathrm{food} \mathrm{and} \mathrm{puri-}$ fied water, with free access to drinking water and standard pelleted diet. All rats were allowed to adapt to the new environment for one week before the study. The work was conducted in accordance with Guide for the Care and Use of Laboratory Animals and approved by the Ethno botany, Department of Natural Sciences, High Normal School of Kouba, Algiers. All the experiments were carried out according to the guidelines of the Institutional Animal Care Committee of the Algerian Higher Education and Scientific Research (Agreement Number 45/DGLPAG/DVA.SDA.14).

\section{Preliminary phytochemical screening}

Phytochemical screening was performed to identify phytochemicals, such as alkaloids, carbohydrates, coumarins, cardiotonic glycosides, steroids and triterpenes, flavonoids, phenols, naphtho- and anthraquinones, saponins, sesquiterpene lactones, tannins, and terpenes in the aqueous extract of Origanum floribundum leaves, with the standard procedures as previously described by Harborne, ${ }^{9}$ Trease and Evans. ${ }^{10}$ The results were evaluated by visual inspection for change in color or precipitation.

\section{Oral acute toxicity test}

The oral acute toxicity study was performed as per the guidelines of Organization for Economic Cooperation and Development (OECD; guideline 423). ${ }^{11}$ Nulliparous healthy female rats were used for this study. Animals were kept under standard conditions for five days. Limit test was performed at $2000 \mathrm{mg} / \mathrm{kg}$ per os as single dose. The rats were divided into 2 groups, with 3 animals in each group. The control group received normal saline at $1 \mathrm{~mL} / \mathrm{kg}$ by gavage while the treated group received $2000 \mathrm{mg} / \mathrm{kg}$ of Origanum floribundum aqueous extract. A total of 3 nulliparous and nonpregnant female rats (aged 9-10 weeks) were used, and each rat received a plant extract. Both groups were observed closely for any toxic effect within first $6 \mathrm{~h}$ and then at regular intervals for a total period of 14 days to note any toxicity signs (changes in skin and fur, eyes, mucous membranes, respiratory, circulatory, autonomic and central nervous systems) and to record any mortalities.

\section{Antidiabetic activity}

\section{Oral glucose tolerance test}

Glucose tolerance test was used to determine the rate at which glucose was cleared from the blood after the administration of a massive dose of glucose. The acclimatized animals were fasted for 24 hours with water ad libitum, normal rats were divided into four groups and each group consisted of six animals. Group I served as control, received $5 \%$ Tween 80 in distilled water at $5 \mathrm{~mL} / \mathrm{kg}$ b.w.p.o. Group II received a reference drug, $5 \mathrm{mg} / \mathrm{kg}$ b.w. of Metformin p.o, whereas other Groups III and IV received the plant extract (200 and $400 \mathrm{mg} / \mathrm{kg}$ b.w., respectively). Then, $30 \mathrm{~min}$ after the administration of test samples, the rats of all the groups were loaded with Glucose $(2 \mathrm{~g} / \mathrm{kg})$ after half an hour of drug administration. Blood samples were taken via the tip of the tail vein. The blood was collected at times $0,30,60,90$ and $120 \mathrm{~min}$. The Accucheck Glucometer was used to determine the level of glucose in blood by Jain et al., ${ }^{12}$ and Balamurugan et al. ${ }^{13}$

\section{Effects of Origanum floribundum aqueous extract on blood glucose levels in induced diabetic rats}

\section{Induction of experimental diabetes}

The albino rats weighing 150-200 g of either sex were allowed to fast for 24 hours prior to experimentation. The animals were weighed and hyperglycemia was induced by a single dose of alloxan monohydrate dissolved in sterile normal saline and administered by a single dose of intraperitoneal injection of $150 \mathrm{mg} / \mathrm{kg}$ body weight. Glucose solution $(1 \%, \mathrm{w} / \mathrm{v}) 10 \mathrm{~mL} / \mathrm{kg}$ was immediately administered orally to alloxan-treated rats in order to prevent transient hypoglycemia. Fasting serum glucose levels were estimated using Accu-check Glucometer. The rats exhibiting serum glucose more than $300 \mathrm{mg} / \mathrm{dL}$ were considered hyperglycemic and included in the study by Vogel et al. ${ }^{14}$ and Nagappa et al. ${ }^{15}$

\section{Experimental design}

The diabetic rats were divided into five groups, each containing six animals:

i) Group I- Normal control rats received 5\% Tween 80 in distilled water p.o. at $5 \mathrm{~mL} / \mathrm{kg}$ b.w; ii) Group II - Diabetic control rats received 5\% Tween 80 in distilled water p.o.; iii) Group III Diabetic received Metformin at the dose of $5 \mathrm{mg} / \mathrm{kg}$ b.w., p.o.; iv) Group IV - Diabetic rats received Origanum floribundum aqueous extract (200mg/kg b.w., p.o.); v) Group V - Diabetic rats received Origanum floribundum aqueous extract $(400 \mathrm{mg} / \mathrm{kg}$ b.w., p.o.).

The effects of Origanum floribundum aqueous extract in normal and diabetic rats were observed by measuring fasting blood glucose and changes in body weight. The administrations of extracts were continued for 21 days, once daily. Blood samples were collected through the tail vein on days 1, 7, 14 and 21 after drug administration and the blood glucose levels and changes in body weight were estimated.

\section{Statistical analysis}

All data were expressed as mean \pm Standard Error of Mean (SEM). Data normality was checked using the Shapiro-Wilk test 
and variance homogeneity was verified with Levene's test. Then, data with evidenced normality were analyzed with parametric tests. The statistical significance between homogenous groups was estimated using one-way ANOVA and post hoc Tukey tests post hoc test applied for multiple comparisons of data. The differences were considered significant, by fixing the $\mathrm{P}$ value as $<0.05$. Analysis was performed using SPSS software package Version 21.

\section{Results}

\section{Phytochemical Screening}

Data of the qualitative phytochemical screening (secondary metabolites) of Origanum floribundum aqueous extract are showed in (Table 1). The latter revealed the presence of various bioactive constituents such as polyphenol, tannins, saponins, terpenoids, flavonoids, steroles, coumarins and alkaloids. However, Anthocyanin, antraquinones and Starchs were absent in the Leaf extract.

\section{Acute toxicity study}

In this study, single oral administration of Origanum floribundum aqueous extracts at a dose of $2000 \mathrm{mg} / \mathrm{kg}$ as per OECD guideline 423 for 14 days did not produce any mortality in the tested animals. No observable signs of toxicity were detected during the experimental period.

\section{Effect of Origanum floribundum aqueous extracts on oral glucose tolerance test}

The plasma glucose levels of the normal rats reached a peak at 30 minutes after the oral administration of glucose and gradually decreased to the pre-prandial level (Table 2). The Metformine (5 $\mathrm{mg} / \mathrm{kg}$ ) and Origanum floribundum aqueous extracts at the dose of 200 and $400 \mathrm{mg} / \mathrm{kg}$ produced significant reduction $(\mathrm{p}<0.05)$ in plasma glucose levels compared with those of the controls at 30 , 60 and $120 \mathrm{~min}$ after glucose load. The significant reduction of the peak levels of blood glucose within 120 min manifested the antidiabetogenic potential of Origanum floribundum extract in the glucose tolerance test models.

\section{Effect of Origanum floribundum aqueous extract on blood glucose levels in induced diabetic rats}

In this study, daily oral administration of Origanum floribundum aqueous extract for 28 days was evaluated for its anti-diabetic activity using alloxan as a diabetic inducing agent. The blood glucose level was increased significantly in untreated alloxan-induced diabetic rats (Table 3) as compared to untreated normal rats $(p \leq 0.05)$. Indeed. The aqueous leaf extract at a dose of 200 and 400 $\mathrm{mg} / \mathrm{kg}$ exhibited significant anti-hyperglycemic activity on $7^{\text {th }}$, $14^{\text {th }}, 21^{\text {th }}$ and $28^{\text {th }}$ day post treatment and caused reduction in blood glucose levels. The antidiabetic activity was not found to be dose dependent as there was no significant difference between the treated groups. Anti-hyperglycemic effect of aqueous extract was similar to the standard drug, Metformin.

\section{Effect of Origanum floribundum aqueous Leaf extracts on body weight in Alloxan- induced diabetic rats}

In the present study, the body weight was slightly increased in normal control rats compared to initial body (Table 4). The extract treatment groups at the dose of 200 and $400 \mathrm{mg} / \mathrm{kg} \mathrm{b.w.} \mathrm{showed} \mathrm{an}$ improvement $(\mathrm{p}<0.05)$ in the body weight in comparison with to initial body. However, body weight of diabetic rats was not restored by treating with metformin.

\section{Discussion}

Diabetes Mellitus (DM) is a metabolic syndrome that has become more and more prevalent and rampant throughout the world. Diabetes incorporates various disorders considered by the raised blood glucose levels hyperglycemia. ${ }^{16}$

Management of diabetes with the agents devoid of any side effects is still a challenge to the medical system. Many of the animal models described apparently share similar characteristic features of type 2 diabetes and have allowed experimentation that would be impossible in humans. None of the known single species is exactly equivalent to human diabetes, but each model act as essential tool for investigating genetic, endocrine, metabolic, morphologic changes and underlying aetiopathogenic mechanisms that could also operate during the evolution of type 2 diabetes in humans. Hence, care must be taken in interpretation and extrapolation of the results obtained from these animal models to humans. ${ }^{17}$

The phytochemical screening shows the presence of flavonoids, terpenoids, tannins and saponins. The presence of these secondary metabolites suggests potentials for the plant as a source of important phytomedicines. Previous studies have indicated that the species of the genus Origanum were well known as medicinal and culinary herbs traditionally used as an antidiabetic agent. ${ }^{18}$ The presence of flavonoids, terpenoids, tannins and saponins explains why the species of the genus Origanum is used for diabetes treatment. Furthermore, the natural constituents could have act separately or synergistically to induce the hypoglycemic effect. ${ }^{19}$

Acute toxicity evaluation is necessary for the authentication of herbal medications safety and for the determination of the safer dose in order to manage the clinical signs and symptoms of the drugs. ${ }^{20}$ The limit test method was not intended for determining a precise LD50 value, but it served as a suggestion for classifying the crude extracts based on the expectation at which dose level the animals were expected to survive. ${ }^{21}$ According to globally harmonized classification system, chemicals are divided into five groups

Table 1. Phytochemical screening of Origanum floribundum leaf extracts.

\begin{tabular}{lc}
\hline Flavonoids & ++ \\
Gallic Tannins & + \\
\hline Cathechic tannins & + \\
Saponins & + \\
\hline Alkaloids & ++ \\
Anthocyanes & - \\
\hline coumarins & ++ \\
Starchs & - \\
\hline Alkaloides & + \\
Anthraquenic derivatives & - \\
$\quad$ Free Anthraquinones & \\
Anthraquinones combinées= Combined anthraquinones & ++ \\
$\quad$ O-Heterosides & \\
$\quad$ C-Heterosides & \\
Sterols and Terpenes & + \\
+++, Very abundant; ++, Abundant; +:, Not abundant; -, Not detected. & ++ \\
\hline
\end{tabular}


on their LD50 basis. Origanum floribundum aqueous extract can be put in group 5 (LD50>2000 mg/kg), in lower toxicity class.

The hyperglycemic peak was decreased to near normal indicating a normal glucose metabolism. This property made it potentially useful in human type 2 diabetes with insulin resistance prone to high postprandial glucose surge. This effect may be due to the potentiation of insulin from existing $\beta$-cells of the islets of Langerhans. Various plants with similar hypoglycemic activity have been reported by Zanatta. ${ }^{22}$

Alloxan-induced hyperglycaemia was considered as a suitable experimental model to study the hypoglycaemic effect of antidiabetic agents in type 2 diabetes mellitus. In alloxan-induced diabetes mellitus, it may lead to the destruction of the beta cells by free radicals produced by alloxan, which results in an impaired pancreatic function and reduced secretion of insulin and consequently hyperglycaemia. ${ }^{23}$

The aqueous leaf extract at a dose of 200 and $400 \mathrm{mg} / \mathrm{kg}$ exhibited significant anti-hyperglycemic activity on $7^{\text {th }}, 14^{\text {th }}, 21^{\text {th }}$ and $28^{\text {th }}$ day post treatment and caused reduction in blood glucose levels. The antidiabetic activity was not found to be dose dependent as there was no significant difference between the treated groups. Anti-hyperglycemic effect of aqueous extract was similar to the standard drug, Metformin. The hypoglycaemic activity of the Origanum floribundum extract may, therefore, be due to inhibition of hepatic glucose production and/or stimulation of glucose utilisation by peripheral tis- sues, especially muscle and adipose tissue. ${ }^{24}$ Also, Origanum floribundum leaf extract may exert its hypoglycemic effect by other mechanisms such as the regeneration of the $\beta$-cells of the pancreas and potentiation of insulin secretion from surviving $\beta$-cells, causing an anti-hyperglycemic effect. ${ }^{25}$ It may also assume that the hypoglycemic effect of the aqueous extract may be attributed to its constituents, out of these secondary metabolites polyphenols, in particular, flavonoids were suggested as the better therapeutic agents in the management of diabetes mellitus and its chronic complications. ${ }^{26-27}$ This could not exclude the intervention of other phytochemical constituents as bioactive hypoglycaemic agents. Hyperglycaemia-induced groups showed a rapid reduction in the body weight which was similar to the result reported by Gandhi and Sasikumar. ${ }^{28}$ It is well known that the loss of body weight is one of the most intuitive indicators of diabetes, which is usually linked to the excessive proteins breakdown. ${ }^{29}$ However, the present study found that there was no weight gain after the treatment with metformin, a result strongly supported by other data. ${ }^{30}$

\section{Conclusions}

At the end, it can be concluded that the Origanum floribundum leaves may contain bioactive constituents with antidiabetic activi-

Table 2. Effect of Origanum floribundum aqueous extracts on oral glucose tolerance test in rats.

\begin{tabular}{lccccc} 
Groups & Dose $(\mathrm{mg} / \mathrm{kg})$ & & Plasma glucose concentration (mg/dl) \\
& & $00 \mathrm{~min}$ & $30 \mathrm{~min}$ & $60 \mathrm{~min}$ & \\
GroupI & & $100.20 \pm 4.4^{\mathrm{a}}$ & $156.30 \pm 3.54^{\mathrm{b}}$ & $152.30 \pm 3.25^{\mathrm{b}}$ & $137.40 \pm 5.06^{\mathrm{c}}$ \\
Group II & 5 & $97.08 \pm 4.8^{\mathrm{a}}$ & $114.80 \pm 4.58^{\mathrm{b}}$ & $107.20 \pm 3.45^{\mathrm{b}}$ & $110.25 \pm 5.28^{\mathrm{b}}$ \\
\hline Group II & 200 & $102.07 \pm 5.2^{\mathrm{a}}$ & $127.60 \pm 4.53^{\mathrm{b}}$ & $123.20 \pm 4.02^{\mathrm{b}}$ & $108.40 \pm 5.45^{\mathrm{c}}$ \\
Group IV & 400 & $98.05 \pm 5.4^{\mathrm{a}}$ & $123.40 \pm 4.07^{\mathrm{b}}$ & $118.60 \pm 3.54^{\mathrm{c}}$ & $102.20 \pm 4.80^{\mathrm{d}}$ \\
\hline
\end{tabular}

Values represent mean \pm SEM $(n=6)$; values for a given group in a row followed by same letter as superscript are not significantly different according to Tukey's multiple comparison procedure (at $\mathrm{p}<0.05$ ).

Table 3. Effect of Origanum floribundum aqueous Leaf extracts on blood glucose levels in Alloxan-induced diabetic rats.

\begin{tabular}{|c|c|c|c|c|c|c|}
\hline \multirow{2}{*}{ Groups } & \multirow[t]{2}{*}{ Treatment } & \multicolumn{5}{|c|}{ Blood Glucose Level (mg/dL) } \\
\hline & & 0 day & $7^{\text {th }}$ day & $14^{\text {th }}$ day & $21^{\text {th }}$ day & $28^{\text {th }}$ day \\
\hline Group I & & $100.20 \pm 11.42^{\mathrm{a}}$ & $102.8 \pm 9.76^{\mathrm{a}, \mathrm{b}}$ & $107.40 \pm 11.93^{b}$ & $104.30 \pm 10.23 \mathrm{~b},{ }^{c}$ & $106.30 \pm 10.50^{\mathrm{a}}$ \\
\hline Group II & Diabetic control & $372.4 \pm 9.82^{\mathrm{a}}$ & $362.6 \pm 8.57^{\mathrm{b}}$ & $342.60 \pm 11.57^{b}$ & $327.20 \pm 2.73^{c}$ & $317.4 \pm 4.19 c$ \\
\hline Group III & Standard Metformin $(5 \mathrm{mg} / \mathrm{kg})$ & $364.8 \pm 14.6^{\mathrm{a}}$ & $289.8 \pm 9.36^{\mathrm{b}}$ & $218.4 \pm 13.41^{\mathrm{c}}$ & $128.5 \pm 7.69^{d}$ & $107.4 \pm 10.23 \mathrm{e}$ \\
\hline Group IV & Alloxan + Extract $(200 \mathrm{mg} / \mathrm{kg})$ & $379.7 \pm 11.58^{a}$ & $279.1 \pm 10^{b}$ & $229.60 \pm 11.53^{c}$ & $134.20 \pm 12.85^{\mathrm{d}}$ & $118.9 \pm 12.38 \mathrm{e}$ \\
\hline Group V & Alloxan + Extract $(400 \mathrm{mg} / \mathrm{kg})$ & $388.05 \pm 11.42^{\mathrm{a}}$ & $294.2 \pm 9.68^{b}$ & $209.40 \pm 9.89^{c}$ & $132.2 \pm 2.80^{\mathrm{d}}$ & $112.6 \pm 11.74$ \\
\hline
\end{tabular}

Values are expressed as Mean \pm S.EM. $(\mathrm{n}=6)$; Different superscript letters $(\mathrm{a}-\mathrm{e})$ in the same line indicate differences $(\mathrm{P}<0.05)$.

Table 4. Effect of Origanum floribundum aqueous Leaf extracts on total body weight of alloxan-induced diabetic rats.

\begin{tabular}{|c|c|c|c|c|}
\hline Groups & Treatment & Initial body weight (g) & Final body weight (g) & $\mathbf{P}$ \\
\hline Group I & Normal control & $199.33 \pm 1.86$ & $246.25 \pm 10.42$ & $0.008^{* *}$ \\
\hline Group II & Diabetic control & $202.65 \pm 6.38$ & $161.08 \pm 4.34$ & $0.010 * *$ \\
\hline Group III & Standard Metformin $(5 \mathrm{mg} / \mathrm{kg})$ & $210.67 \pm 3.23$ & $218.46 \pm 4.34$ & $0.071 \mathrm{NS}$ \\
\hline Group IV & Alloxan + Extract $(200$ mg/kg) & $208.44 \pm 3.23$ & $234.47 \pm 2.73$ & $0.008^{* *}$ \\
\hline Group V & Alloxan + Extract $(400$ mg/kg) & $204.25 \pm 2.57$ & $232.17 \pm 3.58$ & $0.008^{*}$ \\
\hline
\end{tabular}

Values expressed as means \pm SEM. $(\mathrm{n}=6) ;{ }^{*} \mathrm{P}<0.05 ;{ }^{*} \mathrm{P}<0.01$; NS, Not Significant within initial and final body weight each group. 
ty, which can be potentially used for the treatment of diabetes mellitus. The extract possesses an antidiabetic effect that is comparable with that of the standard Metformin drug. Acute toxicity test showed that the plant generally regarded as safe. Further study to substantiate the use of the plant as antidiabetic is recommended.

\section{References}

1. Barcelo A, Rajpathak S. Incidence and prevalence of diabetes mellitus in the Americas. Pan Am J Public Health 2001;10:300-8.

2. Bourne RR, Stevens GA, White RA, et al. Causes of vision loss worldwide, 1990-2010: a systematic analysis. Lancet Glob Health 2013;1:e339-49.

3. Kakkar R. Rising burden of diabetes-public health challenges and way out. Nepal J Epidemiol 2016;6:557-9.

4. Chijioke A, Makusidi M. Mortality patterns among Type 2 diabetes mellitus patients in Ilorin, Nigeria. J Endocrinol Metab Diabetes South Afr 2014;15:79-82.

5. Salehi B, Berkai Y1lmaz Y, Antika G, et al. Insights on the Use of $\alpha$-Lipoic Acid for Therapeutic Purposes. Biomolecules 2019;9:356.

6. Adinortey MB, Agbeko R, Boison D, et al. Phytomedicines used for diabetes mellitus in Ghana: a systematic search and review of preclinical and clinical evidence. Evid Based Complement Altern Med 2019:6021209.

7. Naimi M, Vlavcheski F, Shamshoum H, Tsiani E. Rosemary Extract as a Potential Anti-Hyperglycemic Agent: Current Evidence and Future Perspectives. Nutrients 2017:9;968.

8. Chukwuma CI, Matsabisa MG, Ibrahim MA, et al. Medicinal plants with concomitant anti-diabetic and anti-hypertensive effects as potential sources of dual acting therapies against diabetes and hypertension: a review. J Ethnopharmacol 2019;235:329-360.

9. Harborne JB. Phytochemical Methods. London, UK: Chapman and Hall Ltd; 1973. pp:49-188.

10. Trease GE, Evans WC. Pharmacognosy. 13th (ed). London: ELBS/Bailliere Tindall; 1989. pp. 345-6, 535-6, 772-3.

11. OECD. Guideline for testing of chemicals: acute oral toxicity. Acute Toxic Clas Method; 2001. Available from: https://ntp.niehs.nih.gov/iccvam/suppdocs/feddocs/oecd/oecd gl423.pdf

12. Jain R, Myers TF, Kahn SE, Zeller WP. How accurate is glucose analysis in the presence of multiple interfering substances in the neonate? Glucose analysis and interfering substances. J Clin Lab Anal 1996;10:13-6.

13. Balamurugan B, Duraipandiyan V, Ignacimuthu $\mathrm{S}$. Antidiabetic activity of $\gamma$-sitosterol isolated from Lippia nodiflora L. in streptozotocin induced diabetic rats. Eur J Pharmacol 2011;667:410-8.
14. Vogel H, Vogel W, Schölkens B, et al. Drug discovery and evaluation. 2002:10.1007/3-540-29837-1_18.

15. Nagappa AN, Thakurdesai P, Venkat Rao N, Singh J. Antidiabetic activity of Terminalia catappa Linn fruits. J Ethnopharmacol 2003;88:45-50.

16. American Diabetes Association (ADA). Diagnosis and classification of diabetes mellitus. Diabetes Care 2014;37:S81-S90.

17. Tamma NK. Animal models as an experimental tool in diabetes research. J Drug Delivery Therap 2013;3:152-4.

18. Dundar E, Olgun EG, Isiksoya S, et al. The effects of intrarectal and intra-peritoneal application of Origanum onites L. essential oil on 2, 4, 6 -Trinitrobenzene sulfonic acid induced colitis in the rat. Exp Toxicol Pathol 2008;59:399-408.

19. Marles RJ, Farnsworth NR. Antidiabetic plants and their constituents. Phytomedicine 1995;2:137-189.

20. Ping KY, Darah I, Chen Y, Sreeramanan S, Sasidharan S. Acute and subchronic toxicity study of Euphorbia hirta L. methanol extract in rats. Biomed Res Int 2013;182064.

21. Rao MU, Sreenivasulu M, Chengaiah B, et al. Herbal medicines for diabetes mellitus: a review. Int $\mathrm{J}$ PharmTech Res 2010;2:1883-92.

22. Zanatta L, de Sousa E, Cazarolli LH, et al. Effect of crude extract and fractions from Vitex megapotamica leaves on hyperglycemia in alloxan-diabetic rats. J Ethnopharmacol 2007; 109:151-5.

23. Sabu MC, Kuttan R. Anti-diabetic activity of medicinal plants and its relationship with their antioxidant property. J Ethnopharmacol 2002;81-155-60.

24. El-Khayat Z, Hussein J, Ramzy T et al. Antidiabetic antioxidant effect of Panax ginseng. J Med Plants Res 2011;5:461620 .

25. Mustafa SSS, Eid NI, Jafri SA, et al. Insulinotropic effect of aqueous ginger extract and aqueous garlic extract on the isolated perfused pancreas of streptozotocin induced diabetic rats. Pak J Zool 2007;39:279-84.

26. Saritha M. Flavonoids-The most potent poly-phenols as antidiabetic agents: an overview. Mod Appro Drug Des 2017;1.

27. Li S, Chen H, Wang J, et al. Involvement of the PI3K/Akt signal pathway in the hypoglycemic effects of tea polysaccharides on diabetic mice. Int J Boil Macromol 2015;81:967-74.

28. Gandhi GR, Sasikumar P. Antidiabetic effect of Merremia emarginata Burm. F. in streptozotocin-induced diabetic rats. Asian Pac J Trop Biomed 2012;2:281-86.

29. Ramachandran R, Zhao XF, Goldmam D. Asclla/Dkk/ $\beta$ catenin signaling pathway is necessary and glycogen synthase kinase- $3 \beta$ inhibition is sufficient for zebrafish retina regeneration. PNAS 2011;108:15858-63.

30. Mishra SB, Verma A, Mukerjee A, Vijayakumar M. Antihyperglycemic activity of leaves extract of Hyptis suaveolens L. Poit in streptozotocin induced diabetic rats. Asian Pac J Trop Med 2011;4:689-93. 